\title{
GIS Based Morphometric Analysis of Gudina Wacho Watershed, Western Ethiopia: Suggestion for Surface Irrigation Development
}

\author{
Gebre Gidey $^{1, ~}$, Tekalign Ketema ${ }^{2}$, Gezahegn Gashu $^{3}$, Sime Deressa ${ }^{1}$ \\ ${ }^{1}$ Department of Natural Resource Management, Dambi Dollo University, Dambi Dollo, Ethiopia \\ ${ }^{2}$ Department of Geography and Environmental Studies, Dambi Dollo University, Dambi Dollo, Ethiopia \\ ${ }^{3}$ Department of Natural Resource Management, University of Gondar, Gondar, Ethiopia
}

Email address:

gebregidey09@gmail.com (G. Gidey)

*Corresponding author

\section{To cite this article:}

Gebre Gidey, Tekalign Ketema, Gezahegn Gashu, Sime Deressa. GIS Based Morphometric Analysis of Gudina Wacho Watershed, Western Ethiopia: Suggestion for Surface Irrigation Development. Journal of Water Resources and Ocean Science. Vol. 10, No. 5, 2021, pp. 92-99. doi: 10.11648/j.wros.20211005.11

Received: July 26, 2021; Accepted: August 6, 2021; Published: September 26, 2021

\begin{abstract}
Morphometric analysis of watershed has a vigorous protagonist in predicting site for surface irrigation development. Morphometric analysis is the measurement and mathematical examination of the arrangement of the earth's surface, shape and dimension of its landform. The present study was analyzed the morphometric parameters (liner, areal and relief parameters) of Gudina Wacho watershed for surface irrigation development using GIS. SRTM DEM with 20-meter spatial resolution of the study area was used for the morphometric parameters analysis. The results revealed that the stream orders of the watershed varies from first order to sixth order with a total of 1266 stream numbers measured a total length of $408.98 \mathrm{Kms}$. It is also elongated in shape, contains high value of bifurcation ratio, high value of drainage density, higher stream frequency, have moderate slopes with moderate gravity flow of water, moderate infiltration and higher soil moisture content. These results revealed the rainwater will reach the main channel more rapidly and thus a high response to runoff. Also indicates it is simple to harvest rainwater / runoff water for surface irrigation development and implies as good category for surface irrigation. Over all of the morphometric analysis reflects the watershed is favorable for surface irrigation development and it can benefit the local community to meet the food demand. For more proper evaluation of the watershed for surface irrigation development, further investigation on the physical land suitability analysis of the watershed is needed.
\end{abstract}

Keywords: Morphometric Analysis, Surface Irrigation, GIS

\section{Introduction}

Ethiopia is rain fed agriculture dependent country; with limited use of irrigation for agricultural production [1]. It is estimated that more than $90 \%$ of the food supply in the country comes from rainfed agriculture [2]. The main challenge allied with this rainfed agriculture is the high degree of rainfall variability. Due to this variability, crop failures and food insecurity are frequent in the country [3]. Therefore, the solution for food insecurity could be provided by comprehensive irrigation development that can lead to overcome the effects of rainfall variability and improve the quality of life for rural population $[1,4]$.
Irrigation can be broadly classified into three categories such as surface, sprinkler, and drip irrigation methods. Under such circumstances more than $90 \%$ of the world uses surface irrigation; the reason for this high percentage might be farmers can develop it at farm level with minimal capital investment [2]. To make this farmers' practice more productive the specified area should study its suitability for surface irrigation development before applying it [5]. Accordingly, Pingale et al. [6] reported that morphometric analysis of watershed play a vital role in predicting site for surface irrigation development.

Morphometric is the measurement and mathematical analysis of the configuration of the earth's surface, shape and 
dimension of its landforms [7]. The morphometric includes liner (Stream order, Stream number, Total length streams, Mean length, Bifurcation ratio, Stream length), areal (Watershed area, perimeter, drainage density. length of overland flow, stream frequency, form factor, circulatory ratio and elongation ratio), and relief (Total relief, slop Map and aspect Map) parameters [8]. Although analysis of watershed is important for surface irrigation development, in Ethiopia it has been given insignificant attention and it has been experienced without proper investigation on the potential of the area for it.

Therefore, the present study was analyzed the morphometric parameters of Gudina Wacho watershed for surface irrigation development using GIS techniques. The result will recognize to the local government (regional and district land use planners), and it could serve as a base line for researchers and policy makers' concerning land use planning and management for irrigation.

\section{Materials and Methods}

\subsection{Description of the Study Area}

The study was conducted in Gudina Wacho watershed, Hawa Galan district in Kellem Wollega Zone (KWZ) of Oromia Regional State (Figure 1). The district is located 618 $\mathrm{km}$ far from Addis Ababa and the capital town of the Zone, Dambi Dollo is found at about $642 \mathrm{~km}$ from Addis Ababa. The total land area of the zone is about 9672.4 square kilo meter with altitude ranging above 1200 m.a.s.l. Kellem Wollega zone is bounded by West Wollega Zone in the North, Buno Bedele Zone in the East, Ilu A/Bora Zone in South and Sudan in the West [9].

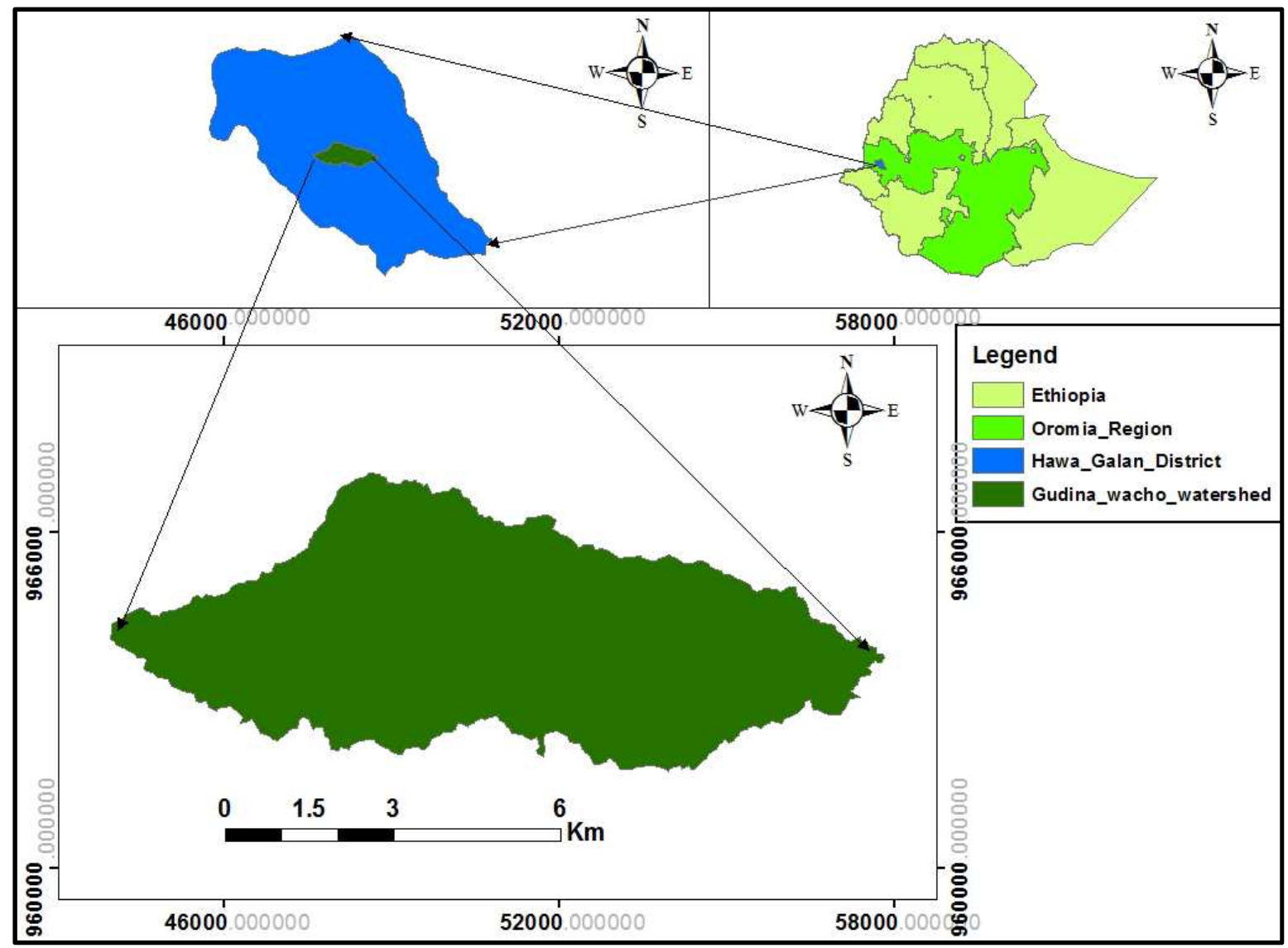

Figure 1. Location of the study area.

The climate of the area is a hot and humid type. This region is marked on most rainfall maps of Ethiopia. Ambient temperature of the Zone ranges from $12-32^{\circ} \mathrm{C}$. The annual rain fall of this zone is minimum $1500 \mathrm{~mm}$, medium 1900 and maximum $3300 \mathrm{~mm}$ [9]. The major soil types of the area are Leptosols, Chromic Luvisols, Vertic Cambisols, Dystric Nitisols, Lithosols and Orthic Acrisols [9].

\subsection{Data Source and Type}

To achieve the objective of the study, Shuttle Radar
Topographic Mission (SRTM) Digital elevation Model (DEM) with 20-meter spatial resolution of the study area was obtained from United State Geological Survey (USGS) website, which is widely used for watershed morphometric parameters analysis [10].

\subsection{Watershed Delineation}

Pour point (out let point) of the drainage was taken using Global Positioning System (GPS) apparatus. Then, using the pour point the boundary of the watershed was delineated 
from the DEM data of the watershed.

\subsection{Data Analysis}

All Parameters of the watershed were computed from the
SRTM using GIS techniques, and the table below (Table 1) presents the formulae that were used in calculating the morphometric parameters.

Table 1. Methods of Calculating Morphometric Parameters.

\begin{tabular}{|c|c|c|}
\hline Morphometric Parameters & Methods & References \\
\hline Stream order $(U)$ & Hierarchical rank & [11] \\
\hline Stream length $(\mathrm{Lu})$ & Length of the stream & [12] \\
\hline Mean stream length (Lsm) & $\begin{array}{l}\mathrm{Lsm}=\mathrm{Lu} / \mathrm{Nu} \\
\text { where, } \\
\mathrm{Lu}=\text { Stream length of order ' } \mathrm{U} \text { ' } \\
\mathrm{Nu}=\text { Total number of stream segments of order ' } U \text { ' }\end{array}$ & [12] \\
\hline Stream length ratio (Rl) & $\begin{array}{l}\mathrm{Rl}=\mathrm{Lu} / \mathrm{Lu}-1 \\
\text { where, } \\
\mathrm{Lu}=\text { Total stream length of order ' } \mathrm{U} \text { ', } \\
\mathrm{Lu}-1=\text { Stream length of next lower order. }\end{array}$ & [13] \\
\hline Bifurcation ratio $(\mathrm{Rb})$ & $\begin{array}{l}\mathrm{Rb}=\mathrm{Nu} / \mathrm{Nu}+1 \\
\text { where, } \\
\mathrm{Nu}=\text { Total number of stream segment of order' } \mathrm{u}^{\prime} \\
\mathrm{Nu}+1=\text { Number of segment of next higher order }\end{array}$ & [14] \\
\hline Mean bifurcation ratio (Rbm) & $\mathrm{Rbm}=$ average of bifurcation ratios of all order & [11] \\
\hline Drainage density (Dd) & $\begin{array}{l}\mathrm{Dd}=\mathrm{L} / \mathrm{A} \\
\text { where, } \\
\mathrm{L}=\text { Total length of streams } \\
\mathrm{A}=\text { Area of watershed }\end{array}$ & [12] \\
\hline Stream frequency $(\mathrm{Fs})$ & $\begin{array}{l}\mathrm{Fs}=\mathrm{N} / \mathrm{A} \\
\text { where, } \\
\mathrm{N}=\text { Total number of streams } \\
\mathrm{A}=\mathrm{Area} \text { of watershed } \\
\mathrm{Rf}=\mathrm{A} /(\mathrm{Lb})^{2}\end{array}$ & [13] \\
\hline Form factor (Rf) & $\begin{array}{l}\mathrm{Rt}=\mathrm{A} /\left(\mathrm{Lb}^{\prime}\right. \\
\text { where, } \\
\mathrm{A}=\text { Area of watershed, } \\
\mathrm{Lb}=\text { Basin length }\end{array}$ & [12] \\
\hline Circulatory ratio (Rc) & $\begin{array}{l}\mathrm{Rc}=4 \pi \mathrm{A} / \mathrm{P}^{2} \\
\text { where, } \\
\mathrm{A}=\text { Area of watershed } \\
\pi=3.14, \mathrm{P}=\text { Perimeter of watershed }\end{array}$ & [15] \\
\hline Elongation ratio $(\mathrm{Re})$ & $\begin{array}{l}\mathrm{Re}=2 \sqrt{(\mathrm{A} / \pi) / \mathrm{Lb}} \\
\text { where, } \\
\mathrm{A}=\text { Area of watershed, } \pi=3.14 \\
\mathrm{Lb}=\text { Basin length }\end{array}$ & [14] \\
\hline Length of overland flow (Lof) & $\begin{array}{l}\text { Lof }=1 / 2 \mathrm{Dd} \\
\text { where, } \mathrm{Dd}=\text { Drainage density }\end{array}$ & [12] \\
\hline
\end{tabular}

\section{Results and Discussion}

\subsection{Linear Morphometric Parameters}

\subsubsection{Stream Orders and Stream Numbers}

The paramount step in analysis of morphometric parameters of watershed is label of stream order. Stream order is a measure of the positions of streams in the chain of command of tributaries [11]. In the present study, the stream orders of the watershed have been ranked according to Strahler [11]. According to Strahler [11], the first - order stream is has no tributaries and that flows from the stream source. A second -order segment is created by joining two first-order segments, a third-order segment by joining two second order segments, and so on. There is no increase in order when a segment of one order is connected by some other lower order. In the present study, the stream order of the watershed varies from first order to sixth order (Figure 2).

The overall stream sections in each order are known as stream number [12]. In the present study, a total of 1266 streams have been counted with the help of ArcGIS software. From the total 1266 number of streams; 1008 first order, 185 second order, 56 third order, 13 fourth order, 3 fifth order and 1 sixth order streams were observed (Figure 2 and Table 2). Amounts of streams are lessening with the upsurge in the order of the streams and thus it can be thought that the watershed is advanced over uniform rock materials [16, 17]. Likewise in Gudina Wacho watershed, the first order of the streams was linked with the maximum number of streams and vice-versa (Table 2). High values of first-order streams show that there is a possibility of abrupt flash floods after heavy rainfall in the down streams [18]. 


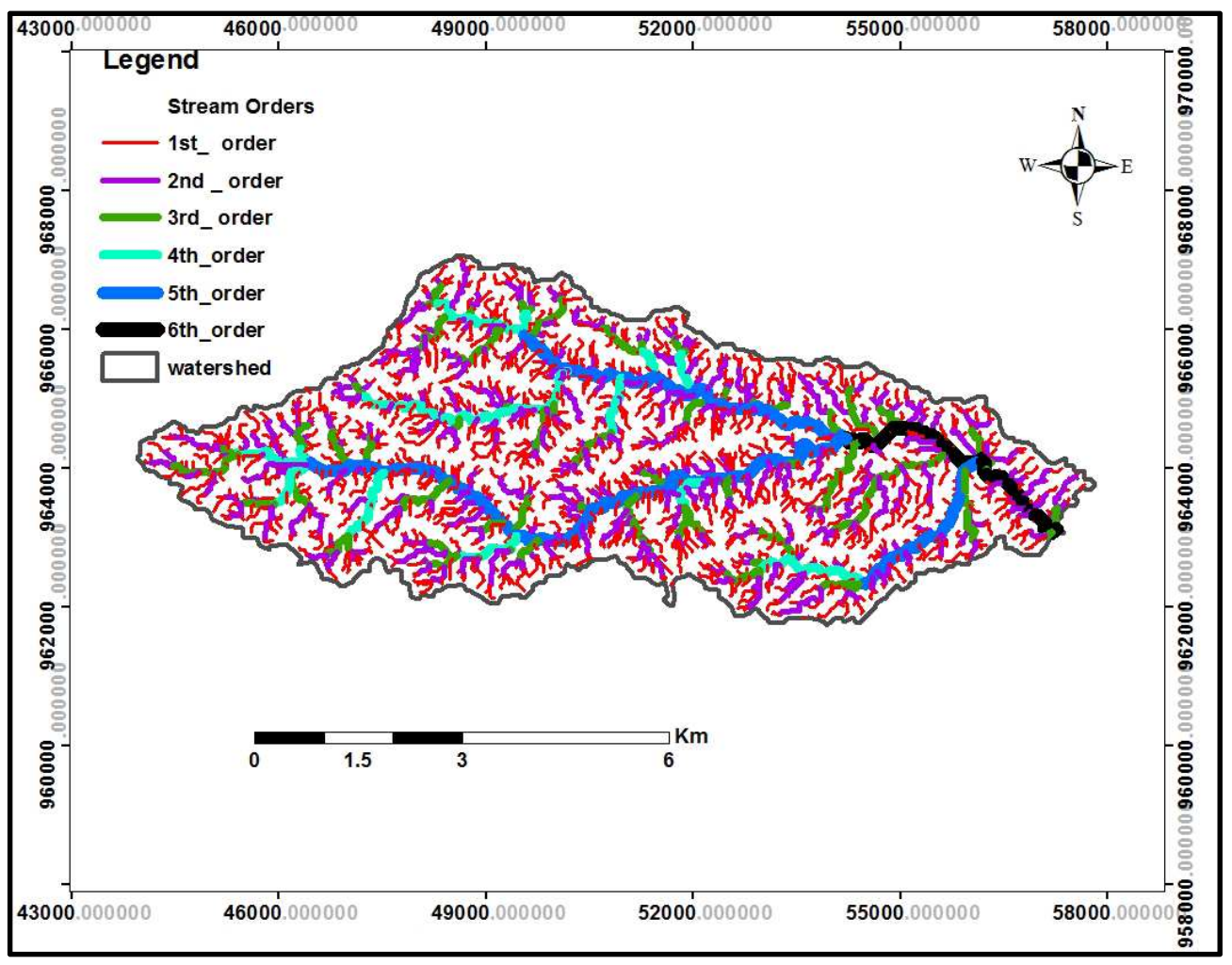

Figure 2. Drainage map with stream orders of the Gudina Wacho Watershed.

\subsubsection{Stream Lengths and Stream Length Ratio}

The stream lengths were generated based on the law proposed by Horton [12]. The total streams lengths of various orders have been measured with the help of calculate geometry of GIS tools. It is revealing of the sequential development of streams and derived from source to mouth of the streams $[16,17]$. The total lengths of Gudina Wacho streams were $408.98 \mathrm{Kms}$. The results reveal that, the firstorder streams were short in length and vice versa (Table 2).

Stream length ratio is the proportion between the lengths of streams in a specified order to the entire length of streams in the subsequent lower order. The values for the Gudina Wacho watershed vary from 0.24 to 1.2 (Table 2), and strongly dependent on the slope. It showed that an important relationship with the surface flow discharge and the erosional stage of the watershed [19]. Similar results were found in
Northern Ethiopia by Gebre et al. [20]. Streams with comparatively short lengths are characteristic of areas with vertical slopes and finer texture, whereas longer lengths of stream are suggestive of horizontal slopes [20].

\subsubsection{Bifurcation Ratio}

It is the ratio between the numbers of stream sections of any specified order to the number the next higher order [22]. Bifurcation ratio for a watershed ranges between 3.0 and 5.0 when the influence of geological structures on the drainage network is slight [21]. Circular watershed has smaller bifurcation ratio than an elongated watershed [23]. In the present study, the values ranging between 3 and 5.5 with mean 4.08. This high value indicated strong structural control on the drainage pattern and also streams that have a higher average flood potential due to abundant tributary sections [23]. The present result agreed with result that was reported by Sarala [21] in Halia drainage area.

Table 2. Linear morphometric parameters of Gudina Wacho watershed.

\begin{tabular}{llllll}
\hline Stream orders & Stream number & Total length streams $(\mathbf{k m})$ & Mean length $(\mathbf{k m})$ & Bifurcation ratio $(\mathbf{N u} / \mathbf{N u}+\mathbf{1})$ & Stream length ratio $(\mathbf{L u}+\mathbf{1} / \mathbf{L u})$ \\
\hline $1^{\text {st }}$ & 1008 & 262.08 & 0.26 & 5.5 & 0.34 \\
$2^{\text {nd }}$ & 185 & 88.7 & 0.48 & 3.3 & 0.28 \\
$3^{\text {rd }}$ & 56 & 25 & 0.45 & 4.3 & 0.54 \\
$4^{\text {th }}$ & 13 & 13.4 & 1.03 & 4.3 & 1.2 \\
$5^{\text {th }}$ & 3 & 16 & 5.3 & 3 & 0.24 \\
$6^{\text {th }}$ & 1 & 3.8 & 3.8 & & \\
Total & 1266 & 408.98 & & & \\
\hline
\end{tabular}

\subsection{Areal Morphometric Parameters}

\subsubsection{Area and Perimeter}

Determining watershed size is necessary to understand the speed of rainwater to reach the targeted area. If the watershed size is larger, it is likely that rainwater will reach the main channel more slowly than in small watershed [24]. The area and perimeter of the Gudina 
Wacho watershed were determined by the spatial analysis tools in Arc GIS, and the results $\left(41.48 \mathrm{Km}^{2}\right.$ and $38.7 \mathrm{Km}$, respectively) revealed the rainwater will reach the main channel more quickly.

\subsubsection{Drainage Density and Stream Frequency}

Drainage density is an expression to indicate the closeness of spacing of channels [21]. The result from morphometric analysis of GudinaWacho watershed revealed that 9.9 $\mathrm{km} / \mathrm{km}^{2}$ drainage density (Table 3). High value of the drainage density which generally values greater than 5 $\mathrm{km} / \mathrm{km}^{2}$ shows an extraordinary density of streams and thus a great reply to runoff [11]. This result may be due to steep slopes and high rainfall [25]. Similar result was found in high rainfall area by Mustaq and Farjana [24].

Stream frequency is defined as the ratio of the total number of stream segments in the watershed to the total area of the watershed [12]. The stream frequency of the watershed was 30.5 (Table 3). It is high due to permeable rocks. A higher stream frequency reflects greater surface run-off that is important for surface irrigation development [18].

\subsubsection{Elongation Ratio and Circularity Ratio}

Elongation Ratio is the ratio between the diameter of a circle of the same area as the watershed and watershed length. Value of elongation ratio varies from 0.6 to 1.0 over a wide variety of climatic and geologic regimes [22]. The elongation ratio of Gudina Wacho watershed was 0.68 (Table 3). It confirmed that the watershed had stretched shape $(<0.7)$ [22].

Circularity ratio is the ratio of the watershed area to the area of circle having the same circumference as the perimeter of the watershed [15]. Circularity ratios range from 0.4 to 0.5 shows powerfully elongated [21]. The low, medium and high values of the circulatory ratio are indications of youth, mature and old stages of the life cycle of the tributary basins, respectively. Gudina Wacho watershed was in the youth stage of its development with a circulatory ratio of 0.35 (Table 3 ).

\subsubsection{Form Factor and Length of Overland Flow}

Form factor indicates the flow intensity of a basin for a defined area [13]. A perfectly circular watershed has form factor value of $>0.78$ [21]. Watershed with large form factors has huge peak flows with short time duration, whereas watershed with small form factor has low peak flows with long time duration [13]. Gudina Wacho watershed is an elongated watershed with lower peak flows of longer duration due to lower form factor value 0.37 (Table 3). Similarly, Gebre et al. [20] found 0.4 form factor value in elongated watershed in Northern Ethiopia.

Length of the overland flow is the length of water over the ground before it gets concentrated into definite stream channels [26]. In the present study, the length of overland flow is $0.05 \mathrm{~km}$ (Table 3 ). This low value indicates that the rainwater maybe travel shorter distance before getting concerted into stream channels [18].

Table 3. Areal morphometric parameters of the watershed.

\begin{tabular}{lll}
\hline S/No & Parameters & Values \\
\hline 1 & Watershed area $\left(\mathrm{Km}^{2}\right)$ & 41.48 \\
2 & Perimeter $(\mathrm{km})$ & 38.7 \\
3 & Watershed length $(\mathrm{Km})$ & 10.6 \\
4 & Drainage density $\left(\mathrm{km} / \mathrm{km}^{2}\right)$ & 9.9 \\
5 & Length of overland flow $(\mathrm{km})$ & 0.05 \\
6 & Stream frequency & 30.5 \\
7 & Form factor & 0.37 \\
8 & Circulatory ratio & 0.35 \\
9 & Elongation ratio & 0.68 \\
\hline
\end{tabular}

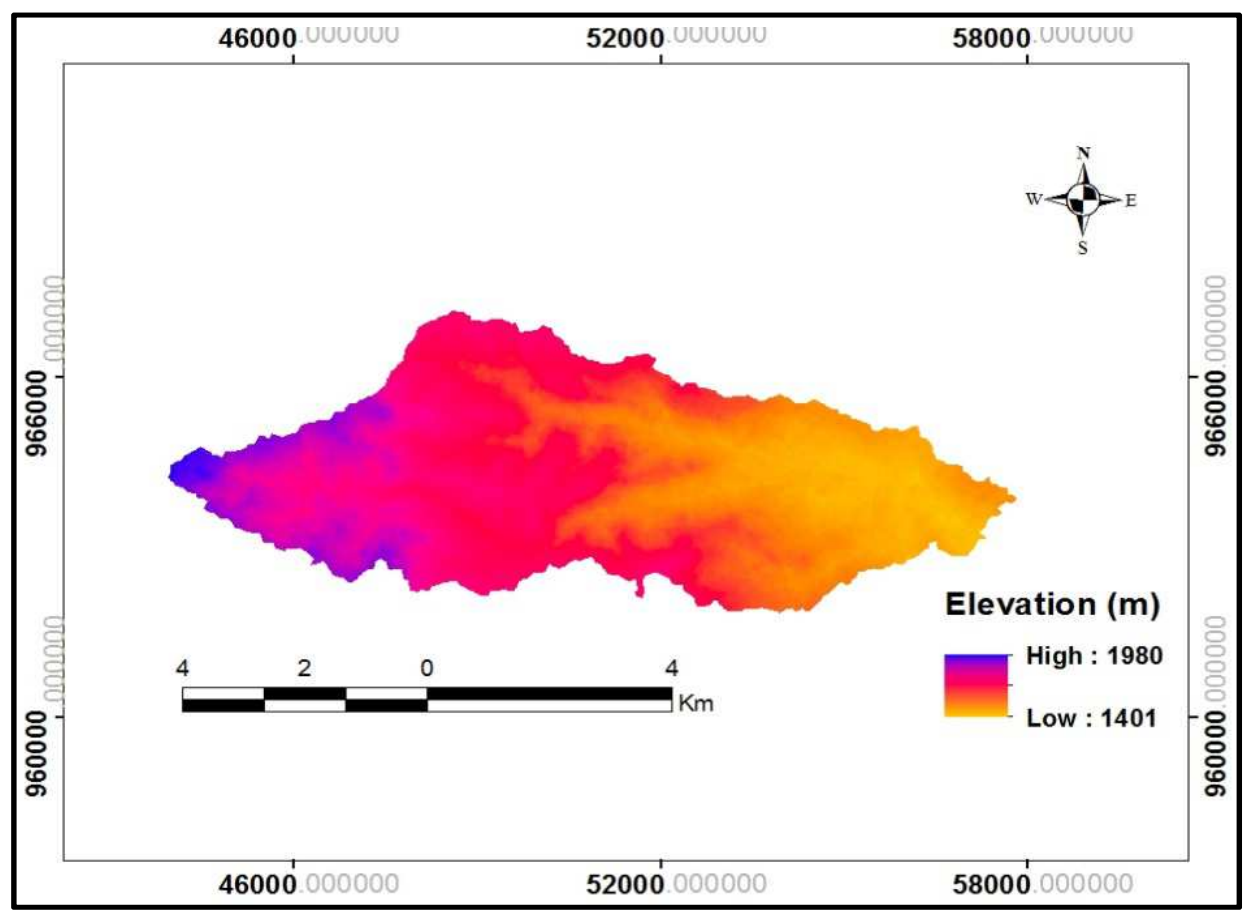

Figure 3. Elevation map of Gudina Wacho watershed. 


\subsection{Relief Parameters}

\subsubsection{Total Relief}

Total relief is the difference between the highest and the lowest points of watershed elevation [27]. It measures the overall steepness of the watershed that indicates the intensity of the effective water flow on the slope of the watershed. The total relief of the Gudina Wacho watershed is 579 m.a.s.l. (Figure 3). Gudina Wacho watershed has 1980 m.a.s.l and 1401 m.a.s.l highest and lowest elevation, respectively. This indicates that the watershed has more enough conditions of runoff [17].

\subsubsection{Slop Map}

Characterizing slope of an area is important, which helps to control the balance between runoff response and soil infiltration rates of topography. Large value of slope causes less infiltration of rainwater and high runoff water (Mohammad, 2017). The slope map of the study watershed was grouped in to five classes in percent for surface irrigation; flat or almost flat $(0-3 \%)$, gentle $(3.1-5 \%)$, moderately steep $(5.1-8 \%)$, steep (8.1-16\%) and very steep (>16\%) (Figure 4).

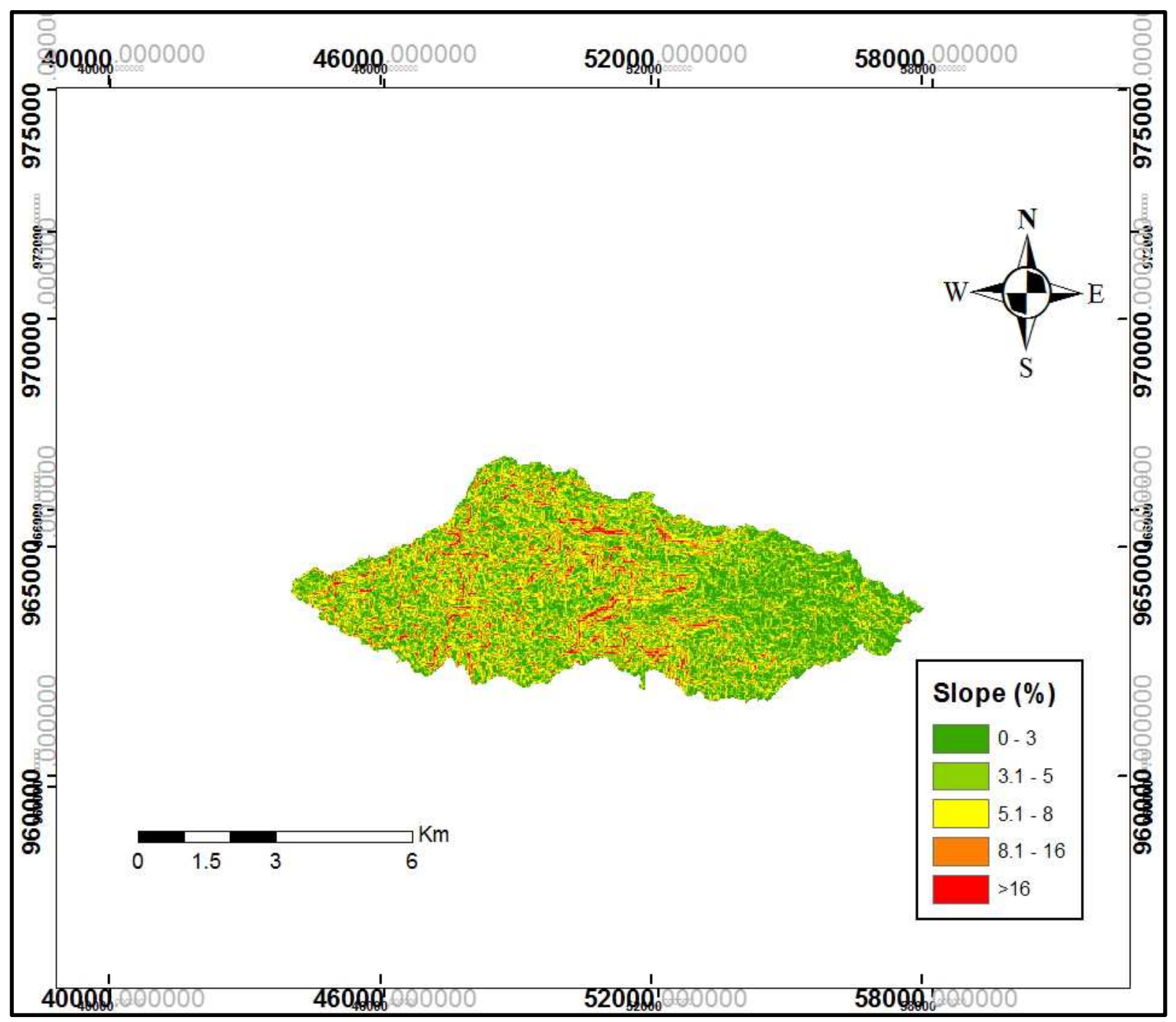

Figure 4. Slops in percent.

Consequently, large portion (51.5\%) of the watershed has gentle slope and can be categorized as good category for surface irrigation development [20].

\subsubsection{Aspect Map}

The aspect map represents the slope direction of watershed from higher to lower elevation and very much important to study the influence of sun light on local climatic condition. A west-facing slope is warmer than an east-facing slope, mainly in the afternoon [20].

The aspect map of the Gudina Wacho watershed was analyzed from DEM. The result indicates large percentage of east-facing slopes. These slopes have comparatively higher soil moisture content and vegetation compared to westfacing slopes of the watershed [16]. 


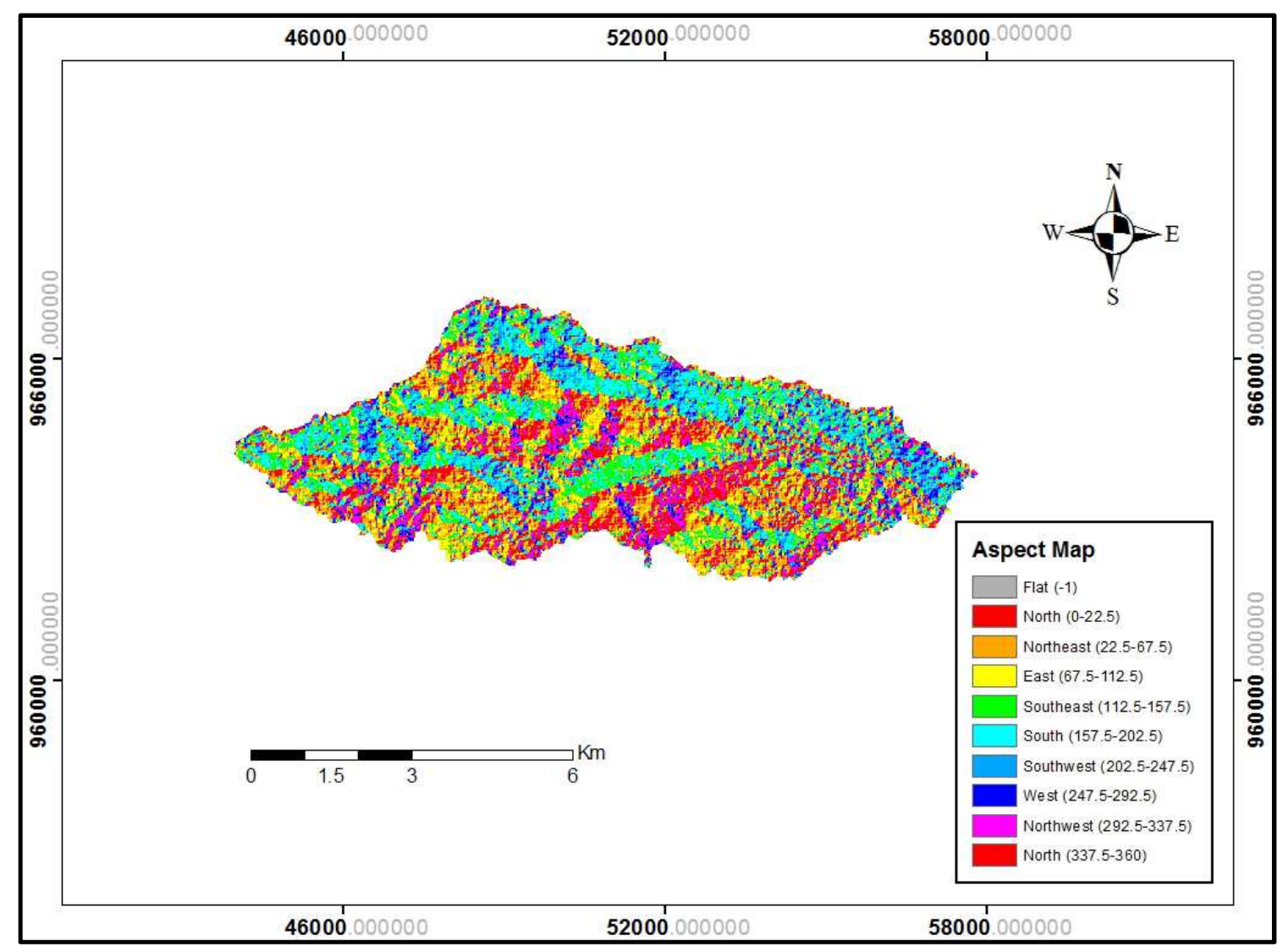

Figure 5. Aspect map of Gudina Wacho watershed.

\subsection{Implications of the Watershed Morphometric Parameters for Surface Irrigation Development}

Morphometric analyses of the watershed showed that the watershed is elongated in shape, contains high value of bifurcation ratio, drainage density and frequency. These results revealed that rainwater reaches the main channel more rapidly and thus a high response to runoff. This indicates that it is humble to harvest runoff water by constructing water harvesting structures in the watershed [20]. It also indicates that the major portion of the watershed have moderate slopes with moderate gravity flow of water, moderate infiltration and higher soil moisture content implies as good category for surface irrigation [17]. Over all of the morphometric analyses reflect the watershed is favorable for surface irrigation development and it can benefit the local community to meet the food demand.

\section{Conclusion and Recommendations}

\subsection{Conclusion}

Sound information on watershed characteristics such morphometric parameters provide a basis for decision making on proper utilization and management of land resources. The importance of morphometric analysis points an opportunity for land use planning for irrigation development. To analyze the morphometric parameters of a watershed, it needs Geographic Information System (GIS) techniques. GIS techniques used to identify the results for surface irrigation development.

In the present study the morphometric parameters of Gudina Wacho watershed was analyzed for surface irrigation development using GIS. The result of the analysis indicates that the watershed is elongated in shape, high runoff discharge and permeable subsoil circumstances. This revealed the watershed is good for surface irrigation on its hydrological status and topographic shape.

\subsection{Recommendations}

In order to sustainably develop the area for irrigation development, the following points should be considered:

1) The watershed needs detail and further hydrogeological investigations to identify its suitability for surface irrigation development.

2) For more proper evaluation of the watershed for surface irrigation development, further investigation on the physical land suitability analysis of the watershed is needed.

\section{References}

[1] Abraham M, Azalu A. "Land Suitability Evaluation for Irrigation in Dejen District, Ethiopia." International Journal of Scientific and Research Publications 3 (2013). 
[2] Awulachew S B, Ayana M. "Performance of irrigation: An assessment at different scales in Ethiopia." Experimental Agriculture 47 (2011): 57-69.

[3] Awulachew S B, Erkossa T, Namara R E. "Irrigation potential in Ethiopia. Constraints and opportunities for enhancing the system, International water Management Institute contributions, Addis Ababa." (2010).

[4] Gebre G. "Impact of Small Scale Irrigation Development on Farmers' Livelihood Improvement in Ethiopia: A Review." Journal of Resources Development and Management 62 (2020): 10-18.

[5] Ibrahim MM, Ibrahim SI, Elhag AM, Dafalla MS. "Surface Irrigation Suitability Assessment of the Soils of Almanaqil Ridge, Gezira State, Sudan. “International Journal of Emerging Trends in Science and Technology 12 (2015): 2803-2814.

[6] Pingale S M, Chandra H, Sharma HC, Mishra SS. "Morphometric analysis of Maun watershed in Tehri-Garhwal district of Uttarakhand using GIS. " International Journal of Geomatics and Geosciences 3 (2012).

[7] Reddy O, Maji GE, Gajbhiye KS. "GIS for morphometric analysis of drainage basins." GIS India 11 (2002): 9-14.

[8] Magesh NS, Jitheshlal KV, Chandrasekar N, Jini KV."GIS based morphometric evaluation of Chimmini and Mupily watersheds parts of Western Ghats Thrissur, India." Earth Science Informatics 5 (2012): 111-121.

[9] KWZ (Kellem Wollega Zone Agricultural office).”Annual report, un published." (2020).

[10] Kabite G, GessesseB. "Hydro-geomorphological characterization of Dhidhessa River Basin, Ethiopia." International Soil and Water Conservation Research 6 (2018): 175-183.

[11] Strahler AN. "Quantitative geomorphology of drainage basins and channel networks". McGraw Hill Book Company, New York, (1964).

[12] Horton RE. "Erosional development of streams and their drainage basins Hydro-physical approach to quantitative morphology." Bull GeolSoc Am (1945): 275-370.

[13] Horton R. E. "Drainage basin characteristics." Trans Am Geophysics Union (1932): 350-361.

[14] Schumm As. "Evolution of drainage systems and slopes in badlands at Perth Amboy, New Jersey." Geological Society of America Bulletin 6 (1956) 597-646, doi: 10.1130.

[15] Miller V. CA. "quantitative geomorphologic study of drainage basin characteristics in the clinch mountain area, Virginia and Tennessee." Columbia University, Department of Geology, Technical Report 3 (1953): 271-300.
[16] Biswas SS. "Analysis of GIS Based Morphometric Parameters and Hydrological Changes in Parbati River Basin, Himachal Pradesh, India." J Geogr Nat Disast 6 (2016): 175-182.

[17] MohammadFR, ChowdhurySJ, Riad A, Quamrul HM. "Morphometric Analysis of Major Watersheds in Barind Tract, Bangladesh: A Remote Sensing and GIS-based Approach for Water Resource Management.” Hydrology 8 (2017): 86-95.

[18] Chitra C, Alaguraja P, Ganeshkumari K, Yuvaraj D, Manivel M. "Watershed characteristics of Kundah subbasin using remote sensing and GIS techniques". Int J Geomatics Geosci 2 (2011): 311-335.

[19] John Wilson JS, Chandrasekar N, Magesh NS. "Morphometric analysis of major sub-watersheds in Aiyar and Karai Pottanar Basin, Central Tamil Nadu, India using remote sensing and GIS techniques". Bonfring Int J Indus Eng Manag Sci 2 (2012).: 8-15

[20] Gebre T, Kibru T, Tesfaye S, Taye G. "Analysis of Watershed Attributes for Water Resources Management Using GIS: The Case of Chelekot Micro-Watershed, Tigray, Ethiopia. " Journal of Geographic Information System 7 (2015): 177190, http://dx.doi.org/10.4236/jgis.2015.72015

[21] Sarala C. "Geographical Information System Based Morphometric Analysis of Halia Drainage Area, Nalgonda District, Andhra Pradesh, India." International Journal of Innovative Research in Science, Engineering and Technology 2 (2013).

[22] Singh RL. India: “A Regional Geography Varanasi.” National geographical Society of India (1971).

[23] Liaqat AKR, Alia Y. "Morphometric Analysis for Soil Erosion Assessment in Parts of Chambal Basin Using Remote Sensing and GIS, Madhya Pradesh." International Journal of Advanced Technology \& Engineering Research 3 (2013): 134-141.

[24] Mustaq Sh, Farjana B. "Analysis of Watershed Characteristics Using Remote Sensing and GIS Techniques." International Journal of Innovative Research in Science, Engineering and Technology 4 (2015).

[25] Singh P, Thakur J K, Singh UC. "Morphometric Analysis of Morar River Basin, Madhya Pradesh, India, Using Remote Sensing and GIS Techniques." Environmental Earth Sciences 68 (2013) 1967-1977, http://dx.doi.org/10.1007/s12665-012-1884-8.

[26] Chorley R. J. "Introduction to physical hydrology". Methuen and Co. Ltd., Suffolk (1969): 211.

[27] Elhag M, Galal KH, Alsubaie A. "Understanding of morphometric features for adequate water resource management in arid environments. " Geosci. Instrum. Method. Data Syst 6 (2017): 293-300. 